\title{
Brazil nut (Bertholletia excelsa) oil emulsions stabilized with thermally treated soy protein isolate for vitamin $D_{3}$ encapsulation
}

\author{
Letícia DOS SANTOS FERREIRA, Thais CARVALHO BRITO-OLIVEIRA , Samantha Cristina DE PINHO ${ }^{1 *}$
}

\begin{abstract}
The main goal of this study was to investigate the possibility of encapsulating vitamin $\mathrm{D}_{3}$ (VD3) in Brazil nut (Bertholletia excelsa) oil emulsions stabilized with thermally treated soy protein isolate (SPI). SPI dispersions were analyzed using intrinsic tryptophan fluorescence, surface hydrophobicity and circular dichroism for a better comprehension of the ingredient's properties. The emulsions produced with SPI dispersions treated at temperatures between 60 and $70{ }^{\circ} \mathrm{C}$ showed higher average droplet diameters $(10-40 \mu \mathrm{M})$ than those treated at 75 and $80^{\circ} \mathrm{C}$. Despite these different droplet diameters, all formulations showed phase separations, requiring the incorporation of xanthan gum (XG) as thickener. Different XG concentrations were, then, tested $(0.1$ to $0.3 \% \mathrm{w} / \mathrm{v})$. The formulation with $0.2 \%$ (w/v) XG and SPI treated at $75{ }^{\circ} \mathrm{C}$ for $15 \mathrm{~min}$ showed the highest stability, and, therefore, was used to produce emulsions encapsulating VD3 at two concentrations (120 and $200 \mu \mathrm{g} / \mathrm{mL}$ ). After 21 days of storage, the emulsion stabilized with $1.0 \%$ (w/v) SPI and $200 \mu \mathrm{g} \mathrm{VD3} / \mathrm{mL}$ preserved $97 \%$ of the vitamin. Therefore, the results revealed it is possible to obtain an efficient formulation for the encapsulation of VD3 using Brazil nut oil as an oily phase and thermally treated SPI as an emulsifier.
\end{abstract}

Keywords: soy protein isolate; encapsulation; cholecalciferol.

Practical Application: Brazil nut oil emulsions stabilized with SPI protected VD3 and can be used to enrich food products.

\section{Introduction}

Cholecalciferol (or vitamin $\mathrm{D}_{3}$ ) is a liposoluble vitamin synthesized in the epidermis by the irradiation of ultraviolet sunlight, which converts 7-dehydrocholesterol into previtamin $\mathrm{D}_{3}$ (Paixão \& Stamford, 2004). This compound is then quickly converted to vitamin $\mathrm{D}_{3}$ (VD3) (Holick, 2007). Different factors, however, can decrease the synthesis of VD3 in the epidermis (e.g., by using sunscreen) and/or compromise its absorption by the organism (e.g., the aging process, or the use of certain drugs for chronic diseases, and fat malabsorption), causing vitamin D deficiency (Holick, 2017; Holick \& Chen, 2008).

Such deficiency is associated with several health problems, including stunted growth and rickets in children and accelerated osteopenia and osteoporosis, with an increased risk of cancer and cardiovascular disease in adults (American Geriatrics Society Workgroup on Vitamin D Supplementation for Older Adults, 2014; Jorge et al., 2018). Therefore, the incorporation of VD3 in foods is considered an alternative to increase the daily intake of this compound.

Even though this incorporation can be challenging due to the hydrophobicity of VD3, it is known that lipid vehicles can significantly increase the absorption of lipophilic compounds (Porter et al., 2007). Therefore, the encapsulation of VD3 in emulsified lipid carriers can be suitable for protecting and delivering such components in a variety of food products (Chaari et al., 2018; Golfomitsou et al., 2018).
An interesting lipid source for food applications is the Brazil nut (Bertholletia excelsa), an important commodity extracted from Amazon palm trees and known for their high content vitamins and minerals, including selenium (Cardoso et al., 2017). Adequate intake of selenium is essential for proper thyroid and immune system functions (Silva et al., 2017), and is required to decrease the risk of cardiovascular diseases (Santos et al., 2017) and protect against oxidative stress (Lemire et al., 2010). In addition, it is a mixture of saturated (palmitic and stearic), monounsaturated (oleic) and polyunsaturated fatty acids ( $\omega-3$, $\omega-6$ and linoleic) (Yang, 2009).

Even though the properties of the oil phase are important for defining the characteristics of emulsions, a good selection of a suitable surfactant is also fundamental. Among the surfactants mostly applied in the food industry are the proteins, such as the soy protein isolates (SPIs) (Dickinson, 2010; Ozturk \& McClements, 2016). The emulsifying properties of soy proteins have been extensively studied for emulsions (Liu \& Tang, 2013; Zhang et al., 2021) and are highly dependent on their solubility. In the case of commercial SPIs, their solubility tends to be low, requiring pretreatments (e.g., $\mathrm{pH}$ alteration and heating) to improve its emulsifying capacity (Shao \& Tang, 2014).

In this context, the main objective of this study was to select a thermal treatment of SPI dispersions and formulations to produce Brazil nut emulsions stabilized with SPI for encapsulating vitamin 
$\mathrm{D}_{3}$. Different SPI thermal processing conditions were evaluated to increase the emulsifying capacity. After stable emulsions were obtained with thermally treated SPI, vitamin $\mathrm{D}_{3}$ was incorporated in the emulsions, and the effect of such incorporation on the physical and oxidative stability of the emulsions was evaluated.

\section{Materials and methods}

\subsection{Materials}

Emulsions were produced using Brazil nut (Bertholletia excelsa) oil (Miragina, Rio Branco, AC, Brazil), soy protein isolate (84.3\% protein content, Protimarti M-90 - Marsul, Montenegro, RS, Brazil), vitamin $\mathrm{D}_{3}$ (cholecalciferol, purity $>96 \%$ ), from Sigma (St Louis, MO, USA), xanthan gum (Grindsted Xanthan 80, Du Pont, Cotia, SP, Brazil) and deionized water (Direct-Q3, Millipore, Billerica, MA, USA). All other chemicals were reagent grade.

\subsection{Characterization of thermally treated SPI}

The SPI was characterized elsewhere (Brito-Oliveira et al., 2018) regarding its protein solubility, isoelectric point and differential scanning calorimetry (DSC) responses before and after $\mathrm{pH}$ alterations and thermal treatments $\left(60^{\circ} \mathrm{C}\right.$ and $\left.80{ }^{\circ} \mathrm{C} / 30 \mathrm{~min}\right)$. In the present investigation, this ingredient was evaluated before and after the same thermal treatments $\left(60^{\circ} \mathrm{C}\right.$ and $80^{\circ} \mathrm{C} / 30$ minutes) at $\mathrm{pH} 7$ by surface hydrophobicity determinations, intrinsic tryptophan fluorescence determinations and circular dichroism (CD). Surface hydrophobicity analyzes were performed using protocol adapted from Hayakawa \& Nakai (1985), by adding increasing volumes of fluorescent probe 8 -anilinonaphthalene sulfonic acid (ANS) (2mM) up to the samples' saturation. The measurements were performed on a spectrofluorimeter (Perkin Elmer model LS55, Waltham, MA, USA), using an excitation length of $363 \mathrm{nM}$ and a length of where emission sweeping from 383 to $650 \mathrm{nM}$ in $10 \mathrm{nM}$ slit opening. Intrinsic tryptophan fluorescence determinations were performed according to Kalapathy et al. (1997). For circular dichroism (CD) analysis, the SPI samples were dispersed in $0.01 \mathrm{M}$ sodium phosphate buffer $0.4 \%(\mathrm{w} / \mathrm{v})$. Afterwards, the samples were appropriately diluted and analyzed with a Jasco J-1500 spectropolarimeter (Jasco Corporation, Tokyo, Japan), and tested in a $0.2 \mathrm{~cm}$ quartz CD cuvette in the far-UV range (190-260 nM) at room temperature using a scan rate, band width and response of $20 \mathrm{nM} / \mathrm{min}, 4 \mathrm{nM}$ and $1 \mathrm{~s}$, respectively. The results were expressed as the mean residual ellipticity $\left(\mathrm{deg} \cdot \mathrm{cm}^{2} / \mathrm{dmol}\right)$, calculated according to Equation 1, and analyzed by the software Dicroprot (Deléage \& Geourjon, 1993) by the self-consistent method (Sreerama \& Woody, 1993).

$\theta=\frac{M * X}{10 * L^{*} C}$

$\mathrm{X}$ is the observed ellipticity (deg), $\mathrm{M}$ is the mean residual weight ( $M=115$ according to Jiang et al., 2009), $L$ is the pathlength $(\mathrm{cm})$, and $\mathrm{C}$ is the protein concentration $(\mathrm{g} / \mathrm{mL})$. All spectra were obtained as the average of 4 scans after the buffer baseline spectra was subtracted.

\subsection{Production of Brazil nut oil emulsions}

To improve its emulsifying capacity, the SPI was thermally treated using different time vs. temperature binomials. SPI dispersions were hydrated with ultrapure water $(100 \mathrm{~mL})$ and magnetically stirred for $30 \mathrm{~min}$. Afterwards, the dispersions had its $\mathrm{pH}$ adjusted to 7.0 and were heated to different temperatures $\left(60,65,70,75\right.$ and $\left.80^{\circ} \mathrm{C}\right)$ for different lengths of time (15 and $30 \mathrm{~min}$ ) in a thermostatic bath (Marconi, Piracicaba, SP, Brazil). Emulsions were produced by dispersing pretreated SPI ( 0.75 to $2.0 \% \mathrm{w} / \mathrm{v})$ in the oil phase (Brazil nut oil 5\% w/v) using a rotor-stator device (T25, IKA, Staufen, Germany) at 15,000 rpm for $5 \mathrm{~min}$. In the formulations containing xanthan gum (XG) $(0.1-0.3 \%, \mathrm{w} / \mathrm{v})$, the polysaccharide was added slowly to the emulsion under magnetic stirring for $30 \mathrm{~min}$ right after the production, whereas the samples were cooling to room temperature. Sodium benzoate $(0.02 \% \mathrm{w} / \mathrm{v})$ was added to the samples during the magnetic stirring, after the production, to prevent microbiological growth. To select the best formulation of emulsion to encapsulate vitamin D3, different SPI concentrations $(0.75-2.00 \%, \mathrm{w} / \mathrm{v})$ and XG concentrations $(0.1-0.3 \%, \mathrm{w} / \mathrm{v})$ were tested, and the resulting systems were evaluated regarding their droplet average size and size distribution, creaming index, and morphology by optical microscopy (methods described above). The most stable emulsion was used to encapsulate vitamin $\mathrm{D}_{3}(120 \mathrm{and} 200 \mu \mathrm{g} / \mathrm{mL})$, and it was added to the oil phase before emulsification. Emulsions containing VD3 were evaluated in terms of vitamin quantification and lipid oxidation. The emulsions were produced in triplicate and stored under refrigeration $\left(4^{\circ} \mathrm{C}\right)$.

\subsection{Determination of the average size and size distribution}

Average particle sizes and the particle size distributions were obtained by laser diffraction (SALD-201V, Shimadzu, Kyoto, Japan). The samples were diluted with ultrapure water before the measurements.

\subsection{Creaming index}

The emulsions were monitored after their production to determine their creaming index (CI). The creaming is a form of gravitational separation, where the formation of the cream in the dispersion is caused by the upward movement of the droplets due to the fact that they have a lower density than the liquid (aqueous phase). For the determination of CI, aliquots of the dispersions were poured into test tubes and stored under refrigeration. The creaming index was calculated according to Equation 2.

$C I(\%)=\frac{H C}{H T} \times 100$

where $\mathrm{HC}$ is the height of the upper phase (creaming) and HT is the total height of the emulsion.

\subsection{Optical microscopy}

Optical microscopy (contrast and fluorescence) was performed according to a protocol adapted from Abhyankar et al. (2011). For this purpose, Nile Red solutions were prepared $(1 \mathrm{mg} / \mathrm{mL}$ of ethanol) and added to the oil phase (10 $\mu \mathrm{L}$ of dye solution/g 
of lipid) of the emulsions during their production process. The fluorescence imaging data were obtained using a Zeiss Axioplan 2 microscope (Carl Zeiss Microscopy, LLC One Zeiss Drive Thornwood, N., USA) at $40 \times$ magnification with an HBO 100 fluorescence light source.

\subsection{Quantification of encapsulated VD3}

The encapsulated VD3 was quantified according to protocol adapted from Chaves \& Pinho (2020). First, $4 \mathrm{~mL}$ of methanol was added to $250 \mu \mathrm{L}$ of emulsion, and vortexed for $30 \mathrm{~s}$. Afterwards, the samples were submitted to an ultrasonic bath (410US, UNIQUE, Indaiatuba, SP, Brazil) for $5 \mathrm{~min}$ and centrifuged (5430R, Eppendorf, Hamburg, Germany) at 7,000 rpm and $11{ }^{\circ} \mathrm{C}$ for $5 \mathrm{~min}$, and the supernatant was collected. Then, $4 \mathrm{~mL}$ of methanol was added to the bottom of the tube, and the extraction and centrifugation steps were repeated. The supernatants were then mixed and filtered through a nylon membrane with an internal diameter $(13 \mathrm{~mm}$ i.d. and pore sizes of $0.45 \mu \mathrm{M}$, Millex Syringe Filter, Millipore, Billerica, MA, USA). The absorbance values of the filtered liquids were determined with a spectrophotometer (Genesys 10S UV-Vis, Thermo Scientific, Waltham, MA, USA) at a wavelength of $265 \mathrm{nM}$. One calibration curve for each different sample was created by plotting the absorbance at $265 \mathrm{nM}$ versus the known concentration of the standards. Vitamin $\mathrm{D}_{3}$ (dissolved in methanol) was selected as the standard. The known concentration of the standard was added in the samples (without vitamin) extracted with methanol, according to the procedure described above

\subsection{Determination of lipid oxidation}

The lipid oxidation degree of the emulsions was monitored during storage using the quantification of the peroxide index (Shantha \& Decker, 1994) adapted by Brito-Oliveira et al. (2017). Evaluation of lipid oxidation was also performed using TBARS according to Lee et al. (2011).

\subsection{Statistical analyses}

The measurements were performed in triplicate, and mean values and corresponding standard errors were calculated. For the statistical treatment of the experimental data, an analysis of variance (ANOVA) was conducted, followed by Tukey's tests with a $5 \%$ significance level using SAS software version 9.2 (SAS Institute Inc, Cary, NC, USA).

\section{Results and discussion}

\subsection{Preliminary characterization of the SPI}

In a previous study conducted by Brito-Oliveira et al. (2018), the same SPI used in the present investigation was characterized in terms of its solubility and thermal behavior. The obtained results indicated low solubilities at acid $\mathrm{pH}$ values and higher solubilities at neutral and alkaline $\mathrm{pH}$ values, with average solubilities of $32.0 \%$ at $\mathrm{pH} 7,51.6 \%$ at $\mathrm{pH} 9$ and $100 \%$ at $\mathrm{pH}$ 11 (Brito-Oliveira et al., 2018). According to the literature, the low solubilities of commercial SPIs at acid and neutral pHs are related to their extraction process, which involves temperature and $\mathrm{pH}$ alterations, leading to different extents of denaturation (Lee et al., 2003; Brito-Oliveira et al., 2017).

In fact, in their study, Brito-Oliveira et al. (2017) did not verify any endothermic peaks in the differential scanning calorimetry results of nontreated samples of the SPI applied in the present study, indicating that the ingredient was commercialized in its denatured state (Brito-Oliveira et al., 2017). The challenges involved in the application of commercial SPIs, especially related to the solubility profiles, are frequently cited in the literature (Brito-Oliveira et al., 2020) and highlight the importance of developing investigations about the functional properties of these ingredients to increase the possibilities of applications.

In this context and considering the importance of developing a complete characterization of protein ingredients for a more adequate comprehension of their functionality, the SPI was analyzed regarding intrinsic tryptophan fluorescence (Figure 1A) and surface hydrophobicity (Figure 2). These results showed some important modifications of the protein structure due to the different treatments applied, particularly at $80^{\circ} \mathrm{C}$. From intrinsic tryptophan fluorescence data (Figure 1A), it was verified that whereas the SPI samples treated at $60^{\circ} \mathrm{C}$ and $\mathrm{pH} 7$ had a similar fluorescence spectrum to that of the untreated samples, samples heated to $80^{\circ} \mathrm{C}$ presented higher fluorescence intensity, with no peak displacement, suggesting the presence of some structural alterations. An increase in the fluorescence intensity is related to denaturation processes, which may cause tryptophan (Trp) to be more exposed than in the native/nontreated structure (Marangoni et al., 2000). Similarly, the surface hydrophobicity results in Figure 2 showed that the $\mathrm{pH}$ alteration to 7 together with the increase in temperature led to high values of surface hydrophobicity, requiring a higher volume of ANS to saturate the sample. Such increase can be justified by the exposure of hydrophobic groups, a result of the process of protein denaturation (Wang et al. 2014). These results are important, as they showed that even though SPI was commercialized with a certain degree of denaturation (Brito-Oliveira et al., 2017), tryptophan and other hydrophobic groups were not completely exposed, which could affect important functionalities of the protein ingredient, including solubility and emulsifying capacity.

Other important information was obtained from the circular dichroism (CD) spectra, shown in Figure 1B, which indicated that treated SPI dispersions exhibited bands with lower negative intensity than the spectra of untreated samples. CD spectra were analyzed by the self-consistent method (SELCON 3), and the results indicated that samples at $\mathrm{pH} 7$ had lower proportions of $\alpha$-helices and higher proportions of $\beta$-sheet conformations than untreated SPI samples. In comparison to the systems treated at $60{ }^{\circ} \mathrm{C}$, samples treated at $80^{\circ} \mathrm{C}$ for 30 minutes had higher proportions of unordered structures, confirming the increase in denaturation degree with the increase in temperature previously discussed.

All these characterizations are important for the comprehension of the surfactant properties of SPI. According to the literature, the emulsifying capacity of protein ingredients depends on their structure/conformation and polar and nonpolar amino groups. In dispersions, the proteins tend to reorient and realign to minimize the number of thermodynamically unfavorable 


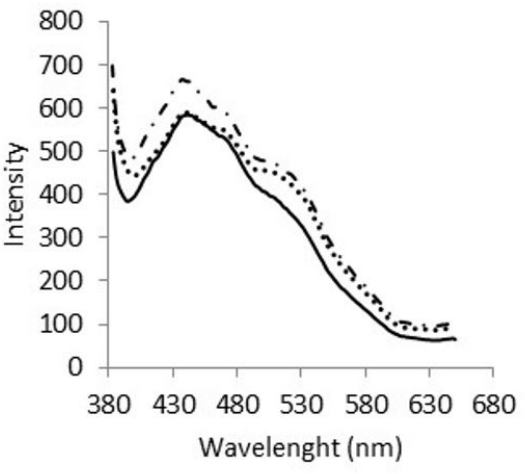

Non treated $\cdots \cdots \cdot . \cdot \mathrm{pH} 7-60^{\circ} \mathrm{C}$

$-\cdots \mathrm{pH} 7-80^{\circ} \mathrm{C}$

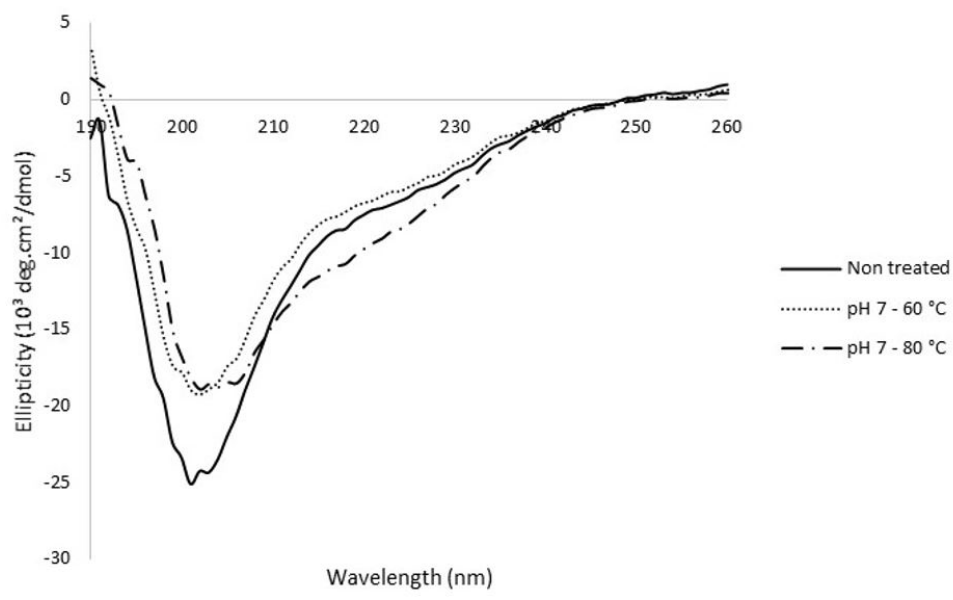

(B)

Figure 1. (A) Intrinsic tryptophan fluorescence data of soy protein isolate without treatment and after different thermal treatments at $\mathrm{pH} 7 \mathrm{and}$ (B) effect of $\mathrm{pH}$ alteration and thermal treatments on the circular dichroism spectra of soy protein isolate.

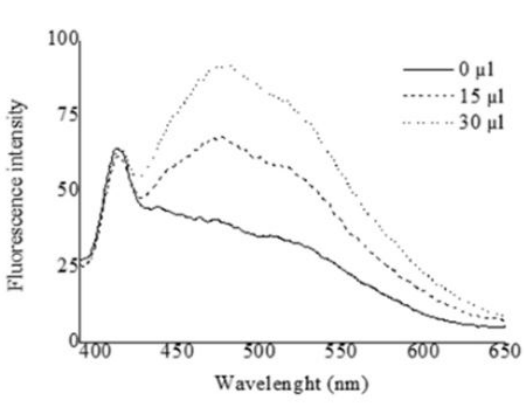

(A) Non-treated

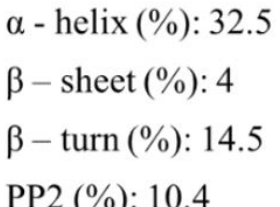

PP2 (\%): 10.4

Unordered (\%): 40.7

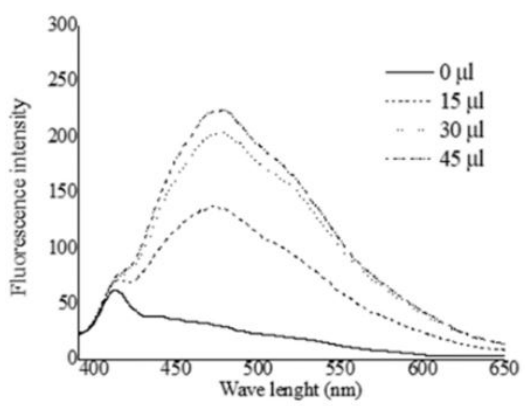

(B) $\mathrm{pH} 7-60^{\circ} \mathrm{C}$

$\alpha$ - helix (\%): 23.3

$\beta-\operatorname{sheet}(\%): 10.2$

$\beta-\operatorname{turn}(\%): 15.1$

PP2 (\%): 9.6

Unordered (\%): 40.7

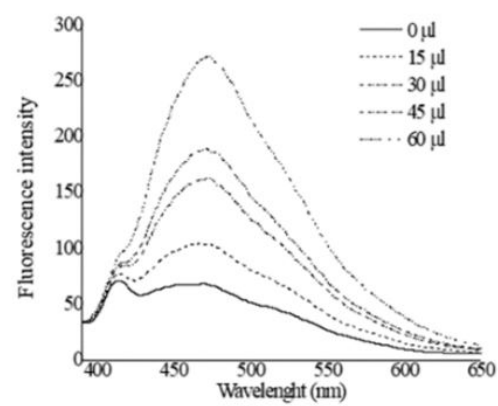

(C) $\mathrm{pH} 7-80^{\circ} \mathrm{C}$

$\alpha$ - helix (\%): 23.8

$\beta-\operatorname{sheet}(\%): 12.7$

$\beta-\operatorname{turn}(\%): 14.4$

PP2 (\%): 9

Unordered (\%): 43.6

Figure 2. Results of surface hydrophobicity of soy protein isolate non-treated and after different thermal treatments at $\mathrm{pH} 7$ and percentages of the different structural conformations obtained by the analysis of CD spectra of SPI dispersions submitted to thermal treatments at $\mathrm{pH} 7.0$

interactions and, therefore, decrease the interfacial tension (Bos \& Van Vliet, 2001; Lam \& Nickerson, 2013).

\subsection{Soy protein isolate as an emulsifier for Brazil nut oil emulsions: thermal treatments and addition of thickening agents (xanthan gum)}

SPI dispersions with different concentrations ( 0.25 to $2.00 \%$, w/v) submitted to various time $v s$ temperature binomials were used to produce Brazil nut oil emulsions. The samples were evaluated to determine their average droplet diameters, and the average droplet diameters are shown in Table 1. Overall, most samples presented average droplet diameters larger than $10 \mu \mathrm{M}$. Although no clear trend of the influence of time on the average diameter was observed on the first day after production, it was possible to observe the average droplet diameters were smaller for the emulsions produced with SPI and treated at 75 and $80^{\circ} \mathrm{C}$. These results are possibly related to the higher degree of denaturation that occurs at higher temperatures, as verified from the higher content of hydrophobic groups, higher intrinsic tryptophan 


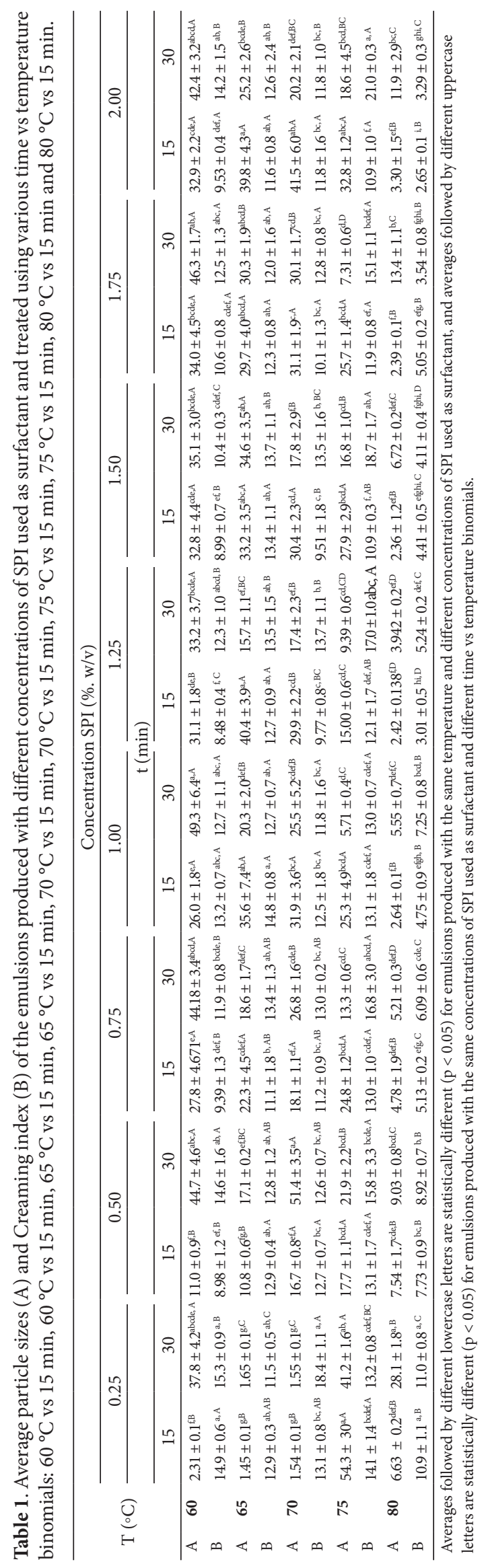


fluorescence values and higher content of unordered protein conformations (section: Preliminary characterization of the SPI).

According to the literature, to act as an emulsifier in oil-in-water emulsions, globular proteins need to adsorb to the surface of freshly formed fine droplets, preventing them from coalescing with their neighbors (Nishinari et al., 2014). For that, such macromolecules should be denatured to expose the hydrophobic amino acids buried in the core of globular proteins (Nishinari et al., 2014). It is known that more hydrophobic proteins tend to orient more readily than less hydrophobic proteins at the surface, allowing hydrophobic groups to interact with the oil and hydrophilic groups to interact with the aqueous phase, lowering the surface free energy and acting as a steric barrier against coalescence and flocculation (Nishinari et al., 2014).

In addition, heating SPIs above $70{ }^{\circ} \mathrm{C}$ causes dissociation of the quaternary structure of the $7 \mathrm{~S}$ and $11 \mathrm{~S}$ fractions, denaturing their subunits and promoting the formation of aggregates via electrostatic forces and hydrophobic and disulfide interactions (Barac et al., 2004). This probably resulted in the increase in the emulsifying capacity of the SPI observed for the binomials using 75 and $80^{\circ} \mathrm{C}$.

These results here presented are similar to those verified by Brito-Oliveira et al. (2017), who concluded that a heat treatment of $60{ }^{\circ} \mathrm{C}$ for $30 \mathrm{~min}$ at $\mathrm{pH} 7$ was not enough to improve its surfactant properties in the production of solid lipid microparticles of palm stearin. On the other hand, according to the same authors, heat treatment at $\mathrm{pH} 7$ and $80{ }^{\circ} \mathrm{C}$ for $30 \mathrm{~min}$ caused enough structural changes in the protein to allow SPI to be suitable to emulsify the oily phase previously mentioned. This fact was also observed in the production of emulsions with Brazil nut oil; that is, the predominant factor for increasing the emulsifying activity does not seem to be the type of oily phase but rather the heat treatment to which the SPI was subjected.

However, although the increase in temperature improved the emulsifying activity of the SPI, the average droplet diameters varied during storage and led to phase separation in all emulsions produced. The degree of instability of the systems was quantified through the creaming index values over 10 days of storage. For all emulsions, except those produced with SPI treated at $80{ }^{\circ} \mathrm{C}$, the IC value varied between 12 and $18 \%$. In addition, the storage period up to the occurrence of phase separation varied from 3 (emulsions produced with SPI treated at $60{ }^{\circ} \mathrm{C}$ ) to 7 days (emulsions produced with SPI treated at $75^{\circ} \mathrm{C}$ ). It was also observed that the emulsions produced with SPI treated at 60 and $65^{\circ} \mathrm{C}$ showed sedimentation of protein.

It was verified, however, that even emulsions stabilized with SPI treated at 75 or $80^{\circ} \mathrm{C}$ (which presented smaller droplet sizes) presented relatively low stability. These results indicated the need for an alternative to improve the stability of the systems. In a similar situation, Brito-Oliveira et al. (2017) incorporated xanthan gum (XG) into the dispersions of solid lipid microparticles and verified the higher stability of the formulations. XG was added at different concentrations (0.1-0.3\%) to the most stable formulations of Brazil nut oil emulsions (produced with SPI concentrations between 0.75 and $1.50 \%$, treated at 75 and $80^{\circ} \mathrm{C}$ ) to verify the best conditions to improve system stability, and the average droplet size of the obtained emulsions on different days of storage is shown in Figure 3.

The obtained data indicated that the XG concentration of $0.1 \%$ was not enough to stabilize the emulsions for more than 7 days, and phase separation was observed. On the other hand, the emulsions incorporated with 0.2 and $0.3 \%$ (w/v) XG remained physically stable, with no apparent phase separation for 40 days. However, all emulsions showed an increase in the average droplet size after 28 days of storage, except the emulsion produced with SPI treated at $75^{\circ} \mathrm{C}$ for $15 \mathrm{~min}$ and thickened with $0.2 \%$ XG.

Based on these results, emulsions produced with $1,1.25$ and $1.50 \%(\mathrm{w} / \mathrm{v})$ SPI and $0.2 \% \mathrm{XG}$ and treated using the binomial $75^{\circ} \mathrm{C}$ vs $15 \mathrm{~min}$ were selected to encapsulate vitamin $\mathrm{D}_{3}$ and to evaluate physical-chemical stability. A temperature of $75^{\circ} \mathrm{C}$ was selected due to VD3 sensitivity to heat, so the lower this process parameter was, the higher the chance that the bioactive compound was better preserved. In addition, a heating time of 15 min was selected because it resulted in emulsions with remarkably similar stability to those produced with SPI treated for $30 \mathrm{~min}$. Finally, the $0.2 \%$ XG concentration was chosen because it presented very similar results to $0.3 \% \mathrm{XG}$ and would be more interesting in terms of production costs.

The three emulsions chosen to continue studying VD3 encapsulation were observed by optical microscopy, and the micrographs obtained are shown in Figure 4. The respective size distribution curves are also shown. The emulsions had a heterogeneous size distribution, as confirmed by the size distribution curve, but there was no significant difference among the three formulations. It is possible to verify the formation of oil droplets dispersed in the aqueous phase (solubilized SPI), in addition to the protein at the interface of these droplets.

\subsection{Physicochemical stability of emulsions encapsulating vitamin $\mathrm{D}_{3}$}

To evaluate the capacity of the emulsions stabilized with SPI to protect VD3, this micronutrient was incorporated at two concentrations, and the emulsion dispersions encapsulating the vitamin were evaluated for 30 days, namely, the average size, span, quantification of VD3 and lipid oxidation. The results obtained during this storage period are shown in Table 2.

It is clear from the data that the average droplet sizes for all emulsions produced remained stable during the storage period. Additionally, the presence of VD3 delayed the lipid oxidation of the emulsions, and no significant difference in this parameter was observed for emulsions with different concentrations of encapsulated bioactive compounds. During the 30 days of storage, the samples were kept refrigerated and protected from light, and there were no changes in their color or odor during that period. Emulsions with VD3 showed lower values than the control (emulsion without VD3). Vitamin $\mathrm{D}_{3}$ probably acted as an antioxidant agent in emulsions, resulting in less lipid oxidation; however, as a consequence, this bioactive compound was degraded over the storage time. In addition, emulsions with a lower concentration of encapsulated VD3 showed higher values of lipid oxidation than those with higher concentrations, 


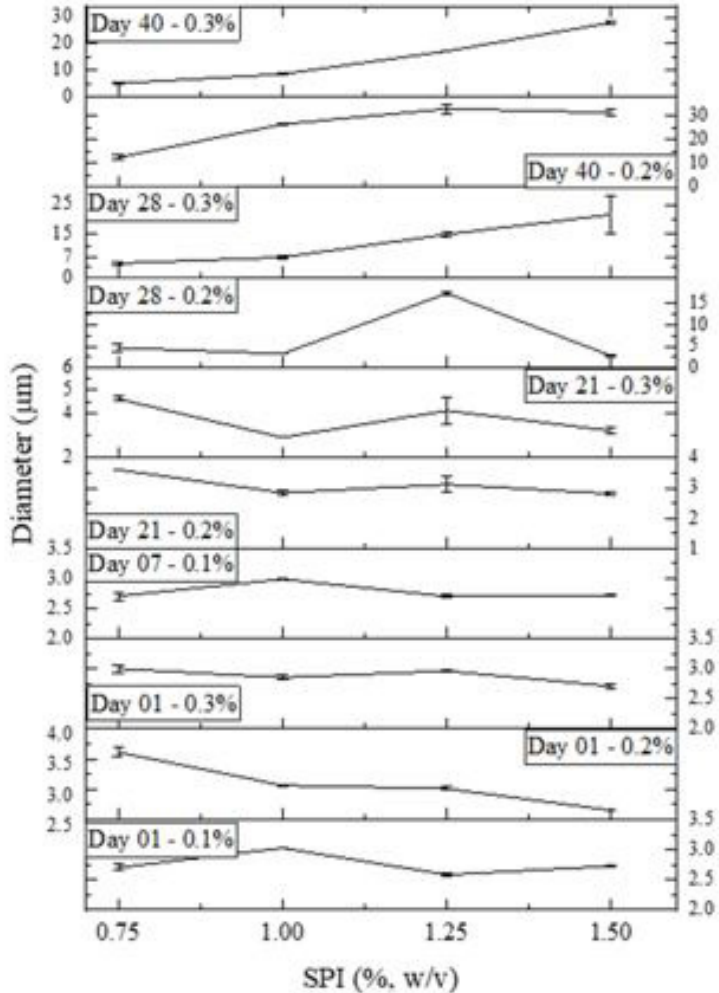

$80^{\circ} \mathrm{C} \times 15 \mathrm{~min}$

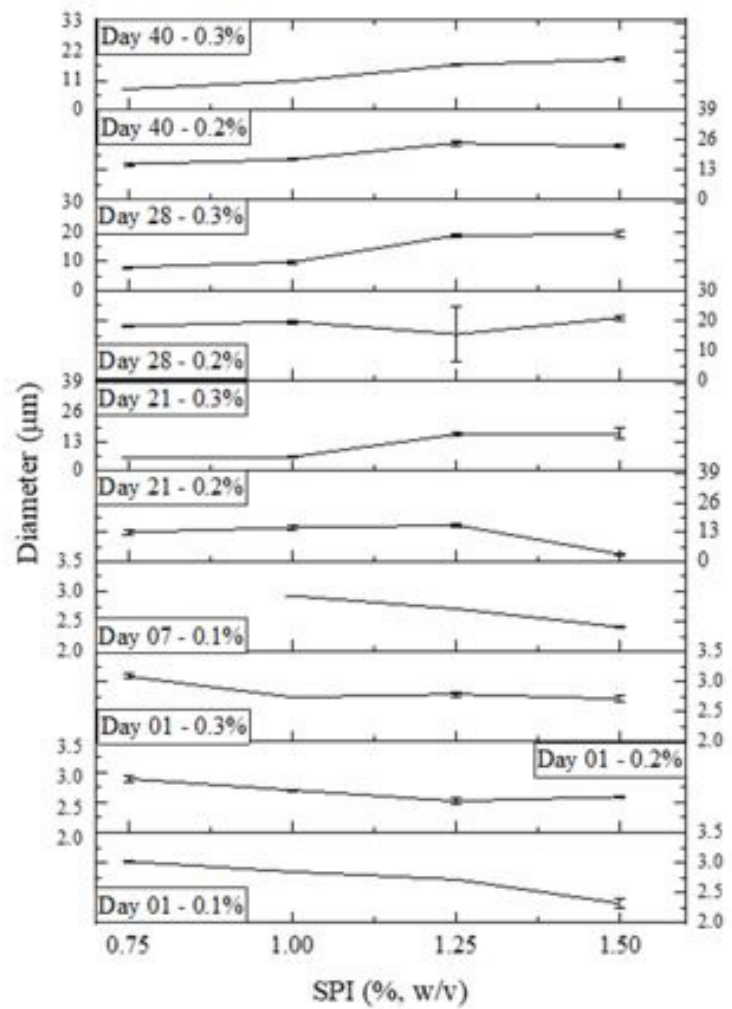

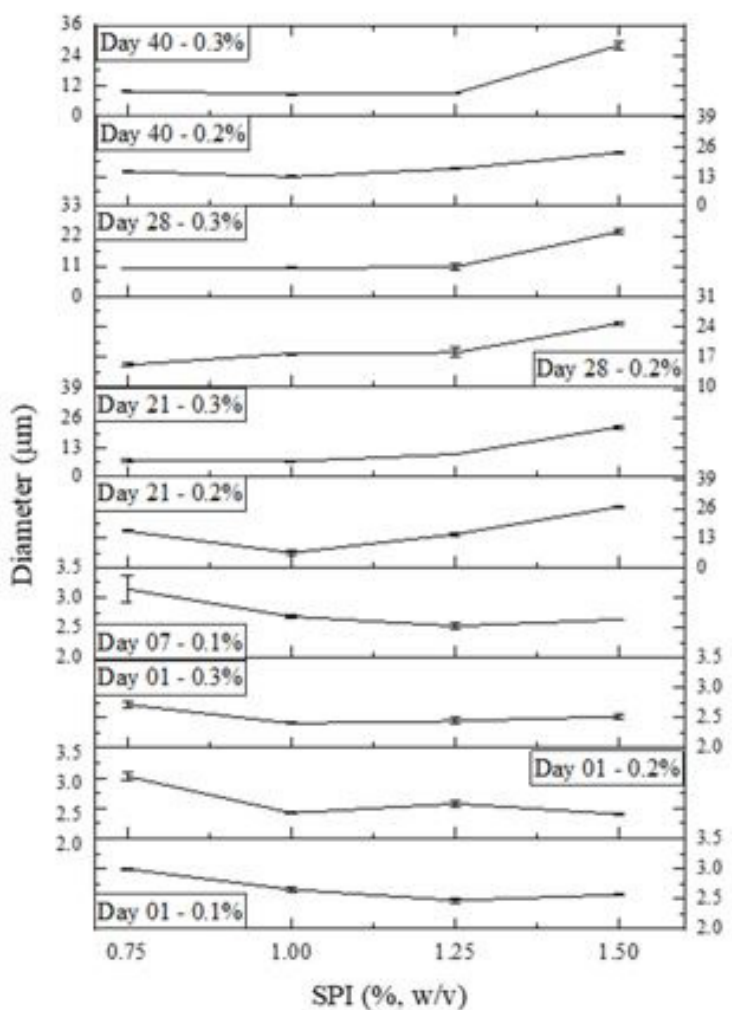

$80^{\circ} \mathrm{C} \times 30 \mathrm{~min}$

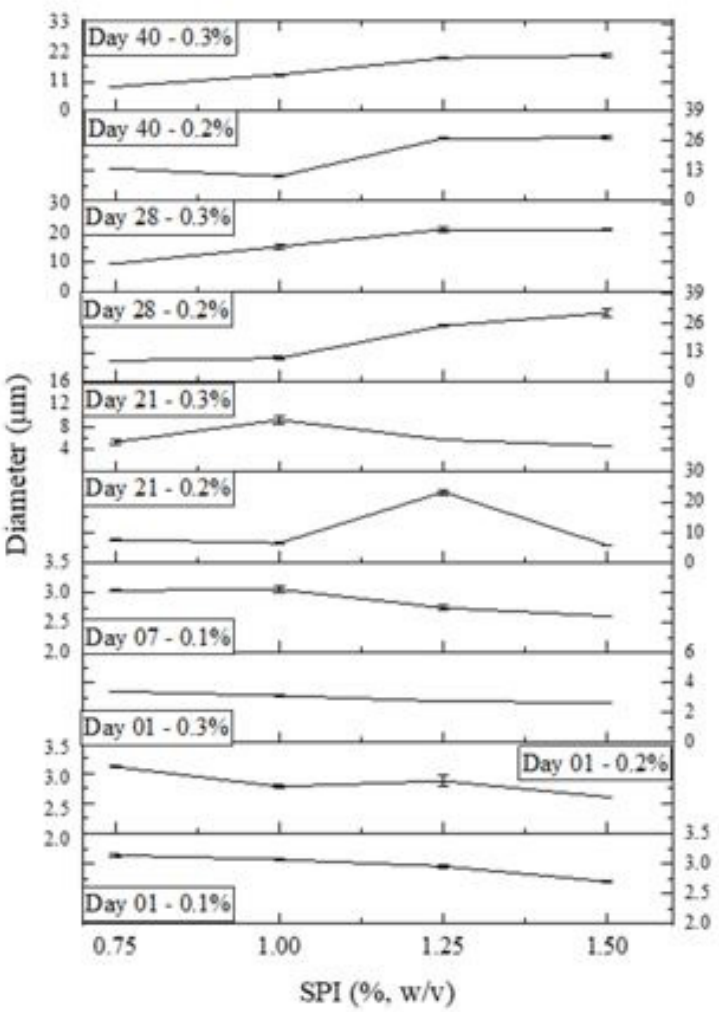

Figure 3. Average particle sizes for SPI concentrations of 0.75 to $1.50 \%(\mathrm{w} / \mathrm{v})$ and thermal treatment $\left(75^{\circ} \mathrm{C}\right.$ for $15 \mathrm{~min} ; 75^{\circ} \mathrm{C}$ for $30 \mathrm{~min} ; 80^{\circ} \mathrm{C}$ for $15 \mathrm{~min}$ and $80^{\circ} \mathrm{C}$ for $\left.30 \mathrm{~min}\right)$ and different concentrations of xanthan gum $(0.1 \%, 0.2 \%$ and $0.3 \%(\mathrm{w} / \mathrm{v}) \mathrm{XG})$. 

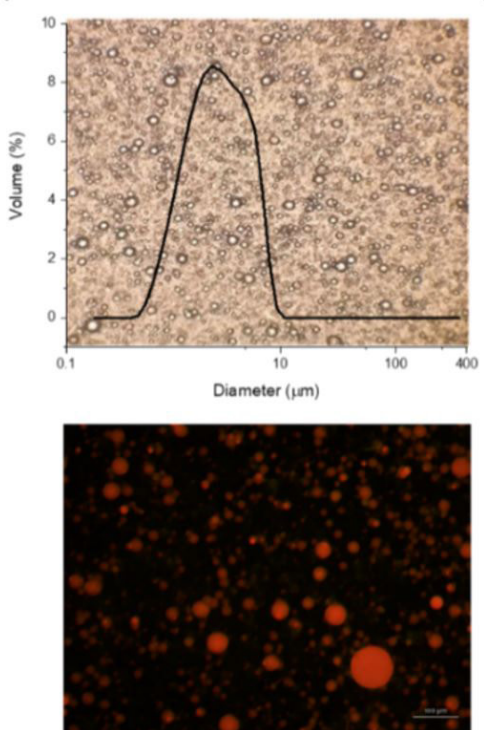
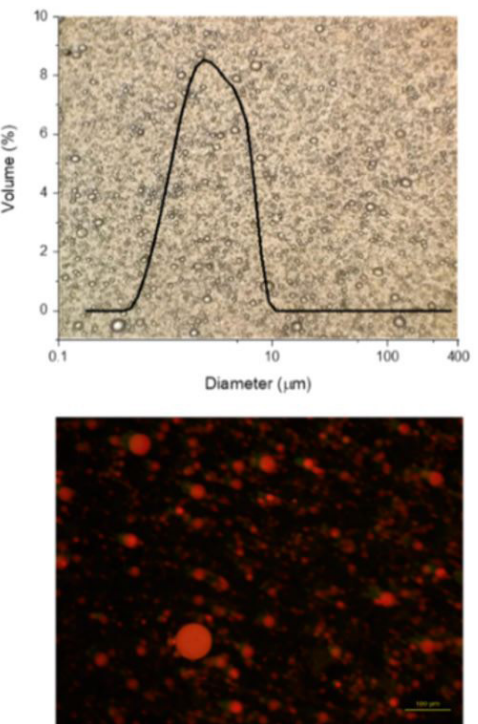

C
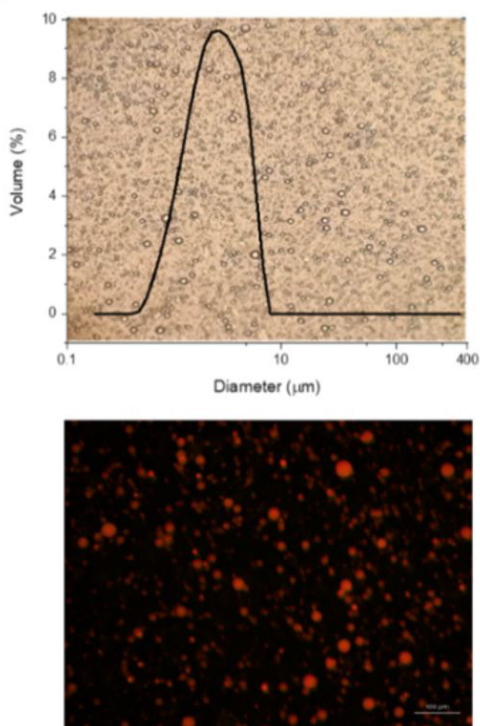

Figure 4. Optical and fluorescence micrographs (magnification: 40x) and size distribution curves of the emulsions selected to encapsulate vitamin $\mathrm{D}_{3}$ : (A) $1.0 \%$ SPI (w/v); (B) $1.25 \%$ SPI (w/v); and (C) $1.50 \%$ SPI(w/v).

Table 2. Values of size measurements, span, and vitamin D quantification of the different formulations of the emulsion at the beginning and end of the storage period.

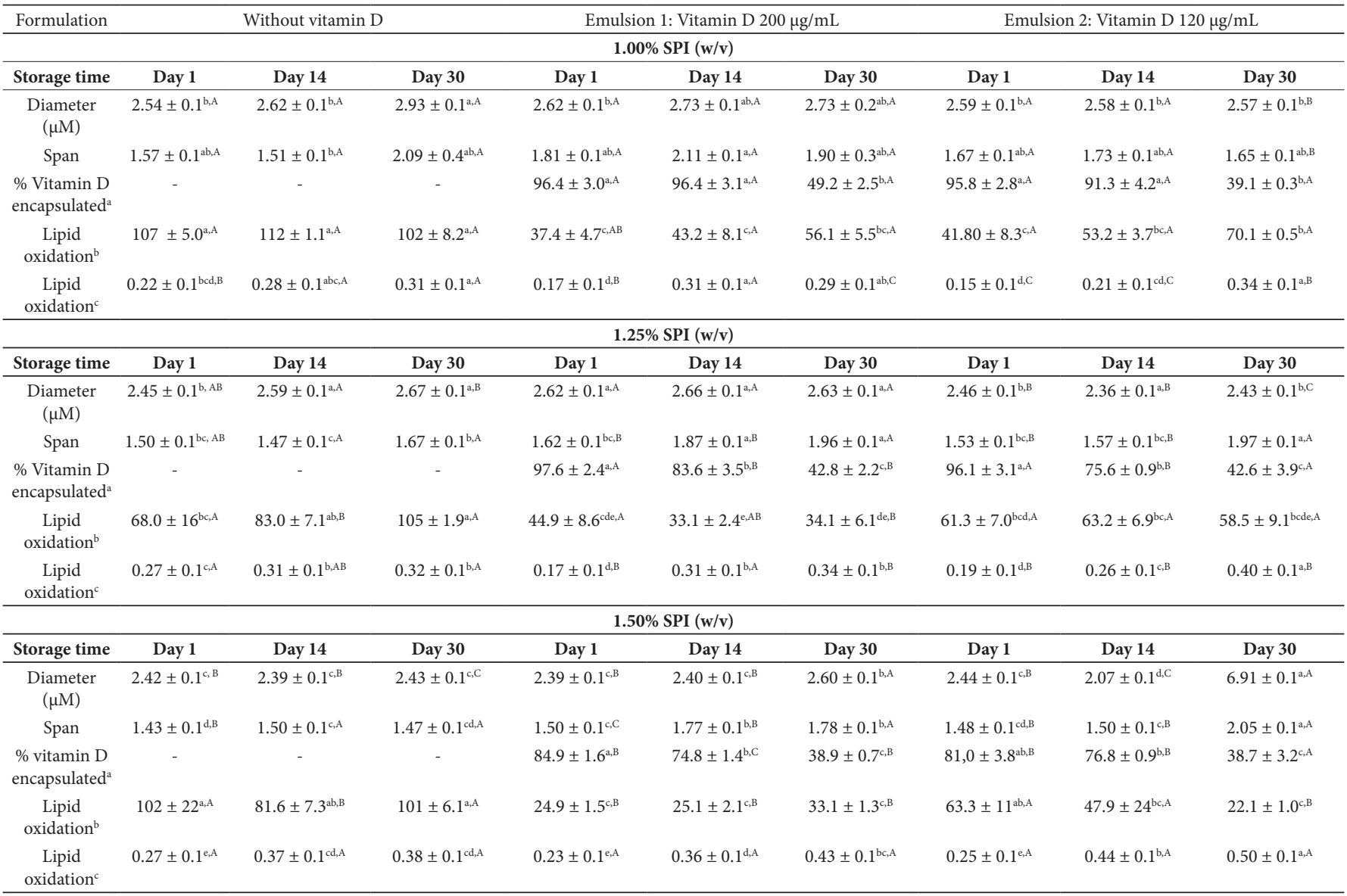

Averages followed by different lowercase letters are statistically different $(\mathrm{p}<0.05)$ for emulsions produced with the same concentrations of SPI used as surfactant and different days of storage, and averages followed by different uppercase letters are statistically different $(\mathrm{p}<0.05)$ for emulsions with the same days of storage and different concentrations of SPI. ${ }^{a}$ Compared to the initial amount of vitamin added to the lipid phase before the production of the emulsion. ${ }^{b}$ Peroxide value: milliequivalents peroxide per kg oil phase. ${ }^{\mathrm{T}}$ TBARS (reactive substances to 2-thiobarbituric acid): mg MDA per kg oil phase. 


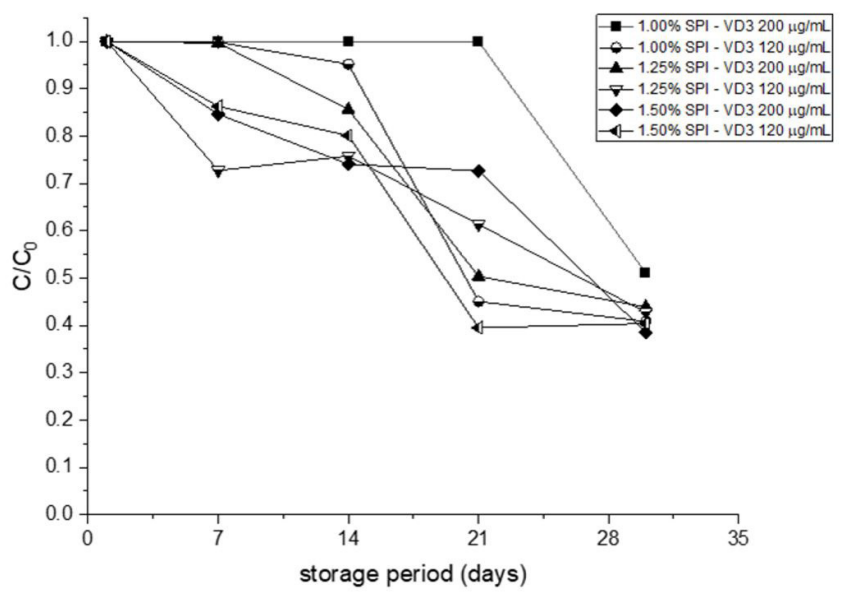

Figure 5. Normalized kinetic profiles of the degradation of VD3 encapsulated in the emulsions over the storage period $(\mathrm{Co}=$ initial concentration of VD3 in the emulsion; $\mathrm{C}=$ concentration of VD3 in the emulsion at the time of sampling).

another indication of the role of the vitamin as an antioxidant. Consequently, the retention values of this vitamin decreased over time.

A factor that may have contributed to the degradation of the encapsulated bioactive compound may have been its distribution in the oil droplets. VD3 may have been partitioned between the oil phase and the location at the oil-water interface, that is, inserted into the protein portion of the emulsion. Nik et al. (2011) studied changes in emulsions stabilized by SPI during in vitro digestion and reported the presence of VD3 in the aqueous phase of the emulsion before the occurrence of oil droplet lipolysis. This may be due to the possibility of the vitamin being retained in the hydrophobic groups of the SPI (instead of only in the oil phase of the emulsion), contributing to decreasing stability over time, as the vitamin would be less protected when it is incorporated into the protein and not in the oily phase. Another factor that may have contributed to the decrease in vitamin D content over time is that it may have migrated to the surface of the drop during storage, leading to a rapid decrease in the percentage of encapsulated vitamin (Khalid et al., 2016).

VD3 encapsulation was also evaluated by analyzing the degradation profiles, as shown in Figure 5.

It is clear that the degradation of VD3 occurred in all formulations, as already seen in Table 2, but it is very noticeable that it occurred at different rates. There is a clear trend towards the higher degradation of the vitamin in the emulsions encapsulating a lower concentration, which may be because this vitamin acted as an antioxidant, as previously cited.

\section{Conclusions}

The data obtained in the present study showed that the encapsulation of VD3 in emulsions produced with Brazil nut oil and stabilized with thermally treated SPI is a feasible alternative for further applications in the fortification of food products. It is quite noticeable that the heat treatment protocols proposed for SPI dispersions caused significant structural changes, enough to improve the physical stability of the emulsions produced. The operational simplicity of the heat treatment protocols proposed for a highly insoluble commercial SPI is an important aspect to be considered, which reinforces the interest in the data obtained in the present study. In addition, the ability of the produced emulsions to preserve the encapsulated VD3 for a significant storage time is an important asset. Finally, the use of Brazil nut oil in the formulation of food products adds economic value to this raw material, which is remarkably interesting due to its nutritional richness in selenium.

\section{Acknowledgements}

The authors thank CAPES (Conselho de Formação de Pessoal de Nível Superior, Brazil, finance code 001) and FAPESP (Sao Paulo State Research Foundation, grant 2017/06224-9) for the fellowships of Letícia S. Ferreira and Thais C. Brito-Oliveira, respectively.

\section{References}

Abhyankar, A. R., Mulvihill, D. M., \& Auty, M. A. E. (2011). Combined microscopic and dynamic rheological methods for studying the structural breakdown properties of whey protein gels and emulsion filled gels. Food Hydrocolloids, 25(3), 275-282. http://dx.doi. org/10.1016/j.foodhyd.2010.05.012.

American Geriatrics Society Workgroup on Vitamin D Supplementation for Older Adults. (2014). Recommendations abstracted from the american geriatrics society consensus statement on vitamin D for prevention of falls and their consequences. Journal of the American Geriatrics Society, 62(1), 147-152. http://dx.doi.org/10.1111/jgs.12631. PMid:24350602.

Barac, M., Stanojevic, S., Jovanovic, S., \& Pesic, M. (2004). Soy protein modification: a review. Acta Periodica Technologica, 280(35), 3-16. http://dx.doi.org/10.2298/APT0435003B.

Bos, M. A., \& Van Vliet, T. (2001). Interfacial rheological properties of adsorbed protein layers and surfactants: a review. Advances in Colloid and Interface Science, 91(3), 437-471. http://dx.doi.org/10.1016/ S0001-8686(00)00077-4. PMid:11511044.

Brito-Oliveira, T. C., Molina, C. V., Netto, F. M., \& Pinho, S. C. (2017). Encapsulation of beta-carotene in lipid microparticles stabilized with hydrolyzed soy protein isolate: production parameters, alphatocopherol coencapsulation and stability under stress conditions. Journal of Food Science, 82(3), 659-669. http://dx.doi.org/10.1111/17503841.13642. PMid:28182846.

Brito-Oliveira, T. C., Bispo, M., Moraes, I. C. F., Campanella, O. H., \& Pinho, S. C. (2018). Cold-Set gelation of commercial soy protein isolate: effects of the incorporation of locust bean gum and solid lipids microparticles on the properties of gels. Food Biophysics, 13(3), 226-239. http://dx.doi.org/10.1007/s11483-018-9529-4.

Brito-Oliveira, T. C., Cavini, A. C. M., Ferreira, L. S., Moraes, I. C. F., \& Pinho, S. C. (2020). Microstructural and rheological characterization of $\mathrm{NaCl}$-induced gels of soy protein isolate and the effects of incorporating different galactomannans. Food Structure, 26, 100158. http://dx.doi.org/10.1016/j.foostr.2020.100158.

Cardoso, B. R., Duarte, G. B. S., Reis, B. Z., \& Cozzolino, S. M. F. (2017). Brazil nuts: nutritional composition, health benefits and 
safety aspects. Food Research International, 100, 9-18. http://dx.doi. org/10.1016/j.foodres.2017.08.036. PMid:28888463.

Chaari, M., Theochari, I., Papadimitriou, V., Xenakis, A., \& Ammar, E. (2018). Encapsulation of carotenoids extracted from halophilic Archaea in oil-in-water (O/W) micro- and nano-emulsions. Colloids and Surfaces. B, Biointerfaces, 161, 219-227. http://dx.doi. org/10.1016/j.colsurfb.2017.10.042. PMid:29080506.

Chaves, M. A., \& Pinho, S. C. (2020). Unpurified soybean lecithins impact on the chemistry of proliposomes and liposome dispersions encapsulating vitamin D3. Food Bioscience, 37, 100700. http://dx.doi. org/10.1016/j.fbio.2020.100700.

Deléage, G., \& Geourjon, C. (1993). An interactive graphic program for calculating the secondary structure content of proteins from circular dichroism spectrum. Computer Applications in the Biosciences, 9(2), 197-199. http://dx.doi.org/10.1093/bioinformatics/9.2.197. PMid:8481823.

Dickinson, E. (2010). Food emulsions and foams: stabilization by particles. Current Opinion in Colloid \& Interface Science, 15(1-2), 40-49. http://dx.doi.org/10.1016/j.cocis.2009.11.001.

Golfomitsou, I., Mitsou, E., Xenakis, A., \& Papadimitriou, V. (2018). Development of food grade $\mathrm{O} / \mathrm{W}$ nanoemulsions as carriers of vitamin $\mathrm{D}$ for the fortification of emulsion based food matrices: A structural and activity study. Journal of Molecular Liquids, 268, 734-742. http://dx.doi.org/10.1016/j.molliq.2018.07.109.

Hayakawa, S., \& Nakai, S. (1985). Relationships of hydrophobicity and net charge to the solubility of milk and soy proteins. Journal of Food Science, 50(2), 486-491. http://dx.doi.org/10.1111/j.1365-2621.1985. tb13433.x.

Holick, M. F. (2007). Vitamin D deficiency. The New England Journal of Medicine, 357(3), 266-281. http://dx.doi.org/10.1056/NEJMra070553. PMid:17634462.

Holick, M. F. (2017). The vitamin D deficiency pandemic: approaches for diagnosis, treatment and prevention. Reviews in Endocrine \& Metabolic Disorders, 18(2), 153-165. http://dx.doi.org/10.1007/ s11154-017-9424-1. PMid:28516265.

Holick, M. F., \& Chen, T. C. (2008). Vitamin D deficiency: a worldwide problem with health consequences. The American Journal of Clinical Nutrition, 87(4), 1080-1080S. http://dx.doi.org/10.1093/ ajcn/87.4.1080S. PMid:18400738.

Jiang, J., Chen, J., \& Xiong, Y. L. (2009). Structural and emulsifying properties of soy protein isolate subjected to acid and alkaline $\mathrm{pH}-$ Shifting processes. Journal of Agricultural and Food Chemistry, 57(16), 7576-7583. http://dx.doi.org/10.1021/jf901585n. PMid:19601630.

Jorge, A., Cordeiro, J. R., Rosa, M. L. G., \& Bianchi, D. B. C. (2018). Deficiência da vitamina $\mathrm{D}$ e doenças cardiovasculares. International Journal of Cardiovascular Sciences, 31(4), 422-432.

Kalapathy, U., Hettiarachchy, N. S., \& Rhee, K. C. (1997). Effect of drying methods on molecular properties and functionalities of disulfide bond-cleaved soy proteins. Journal of the American Oil Chemists' Society, 74(3), 195-199. http://dx.doi.org/10.1007/s11746-997-0123-z.

Khalid, N., Kobayashi, I., Neves, M. A., Uemura, K., Nakajima, M., \& Nabetani, H. (2016). Encapsulation of cholecalciferol and ergocalciferol in oil-in-water emulsions by different homogenization techniques. European Journal of Lipid Science and Technology, 19(6), 1-10.

Lam, R. S. H., \& Nickerson, M. T. (2013). Food proteins: a review on their emulsifying properties using a structure-function approach. Food Chemistry, 141(2), 975-984. http://dx.doi.org/10.1016/j. foodchem.2013.04.038. PMid:23790876.
Lee, K. H., Ryu, H. S., \& Rhee, K. C. (2003). Protein solubility characteristics of commercial soy protein products. Journal of the American Oil Chemists' Society, 80(1), 85-90. http://dx.doi.org/10.1007/s11746-003-0656-6.

Lee, S. J., Choi, S. J., Li, Y., Decker, E. A., \& McClements, D. J. (2011). Protein-stabilized nanoemulsions and emulsions: Comparison of physicochemical stability, lipid oxidation, and lipase digestibility. Journal of Agricultural and Food Chemistry, 59(1), 415-427. http:// dx.doi.org/10.1021/jf103511v. PMid:21133433.

Lemire, M., Fillion, M., Barbosa, F. Jr, Guimarães, J. R. D., \& Mergler, D. (2010). Elevated levels of selenium in the typical diet of Amazonian riverside populations. The Science of the Total Environment, 408(19), 4076-4084. http://dx.doi.org/10.1016/j.scitotenv.2010.05.022. PMid:20646739.

Liu, F., \& Tang, C. H. (2013). Soy protein nanoparticle aggregates as pickering stabilizers for oil-in-water emulsions. Journal of Agricultural and Food Chemistry, 61(37), 8888-8898. http://dx.doi.org/10.1021/ jf401859y. PMid:23977961.

Marangoni, A. G., Barbut, S., Mcgauley, S. E., Marcone, M., \& Narine, S. S. (2000). On the structure of particulate gels-the case of salt-induced cold gelation of heatdenatured whey protein isolate. Food Hydrocolloids, 14(1), 61-74. http://dx.doi.org/10.1016/S0268-005X(99)00046-6.

Nik, A. M., Corredig, M., \& Wright, A. J. (2011). Release of lipophilic molecules during in vitro digestion of soy protein-stabilized emulsions. Molecular Nutrition \& Food Research, 55(Suppl. 2), S278-S289. http:// dx.doi.org/10.1002/mnfr.201000572. PMid:21638776.

Nishinari, K., Fang, Y., Guo, S., \& Phillips, G. O. (2014). Soy proteins: a review on composition, aggregation and emulsification. Food Hydrocolloids, 39, 301-318. http://dx.doi.org/10.1016/j.foodhyd.2014.01.013.

Ozturk, B., \& McClements, D. J. (2016). Progress in natural emulsifiers for utilization in food emulsions. Current Opinion in Food Science, 7, 1-6. http://dx.doi.org/10.1016/j.cofs.2015.07.008.

Paixão, J. A., \& Stamford, T. L. M. (2004). Vitaminas Lipossolúveis em alimentos - uma abordagem analítica. Quimica Nova, 27(1), 96-105. http://dx.doi.org/10.1590/S0100-40422004000100020.

Porter, C. J. H., Trevaskis, N. L., \& Charman, W. N. (2007). Lipids and lipid-based formulations: optimizing the oral delivery of lipophilic drugs. Nature Reviews. Drug Discovery, 6(3), 231-248. http://dx.doi. org/10.1038/nrd2197. PMid:17330072.

Santos, M., Silva, F. M. R. Jr, \& Muccillo-Baisch, A. L. (2017). Selenium content of Brazilian foods: a review of the literature values. Journal of Food Composition and Analysis, 58, 10-15. http://dx.doi.org/10.1016/j. jfca.2017.01.001.

Shantha, N. S., \& Decker, E. A. (1994). Rapid, sensitive, iron-based spectrophotometric methods for determination of peroxide values of lipids. Journal of AOAC International, 77(2), 421-424. http://dx.doi. org/10.1093/jaoac/77.2.421. PMid:8199478.

Shao, Y., \& Tang, C. H. (2014). Characteristics and oxidative stability of soy protein-stabilized oil-in-water emulsions: Influence of ionic strength and heat pretreatment. Food Hydrocolloids, 37, 149-158. http://dx.doi.org/10.1016/j.foodhyd.2013.10.030.

Silva, E. C. Jr, Wadt, L. H. O., Silva, K. E., Lima, R. M. B., Batista, K. D., Guedes, M. C., Carvalho, G. S., Carvalho, T. S., Reis, A. R., Lopes, G., \& Guilherme, L. R. G. (2017). Natural variation of selenium in Brazil nuts and soils from the Amazon region. Chemosphere, 188, 650-658. http://dx.doi.org/10.1016/j.chemosphere.2017.08.158. PMid:28923728.

Sreerama, N., \& Woody, R. W. (1993). A self-consistent method for the analysis of protein secondary structure from circular dichroism. 
Analytical Biochemistry, 209(1), 32-44. http://dx.doi.org/10.1006/ abio.1993.1079. PMid:8465960.

Wang, Z., Li, Y., Jiang, L., Qi, B., \& Zhou, L. (2014). Relationship between Secondary Structure and Surface Hydrophobicity of soybean protein isolate subjected to heat treatment. Journal of Chemistry, 2014, 475389. http://dx.doi.org/10.1155/2014/475389.
Yang, J. (2009). Brazil nuts and associated health benefits: a review. Lebensmittel-Wissenschaft + Technologie, 42(10), 1573-1580. http:// dx.doi.org/10.1016/j.lwt.2009.05.019.

Zhang, T., Peng, Q., Xia, Y., Zhang, Y., Myint, K., \& Wu, J. (2021). Steviol glycosides, an edible sweet surfactant that can modulate the interfacial and emulsifying properties of soy protein isolate solution. Journal of Food Engineering, 289, 110264. http://dx.doi. org/10.1016/j.jfoodeng.2020.110264. 